\title{
Evaluation and Reformulation of Ingredients the Indigenous Tumpi Product
}

\author{
Tien Kumalasari ${ }^{1}$, Agussalim Matti ${ }^{*}$
}

${ }^{1}$ Department of Fisheries Agribusinis, Pangkep State Polytechnic of Agricultural, Jl. Poros Makassar-Parepare KM 83 Mandalle, Pangkajene dan Kepulauan, South Sulawesi, Indonesia

2Department of Fisheries products processing technology, Pangkep State Polytechnic of Agricultural, Jl. Poros Makassar-Parepare KM 83 Mandalle, Pangkajene dan Kepulauan, South Sulawesi, Indonesia "Correspondent author: Agussalim Matti: Department of Fisheries products processing technology, Pangkep State Polytechnic of Agricultural, Jl. Poros Makassar-Parepare KM 83 Mandalle, Pangkajene dan Kepulauan, South Sulawesi, Indonesia

\section{ABSTRACT}

The aim of the study was to evaluate and formulate the ingredients of tuna tumpi products, indigenous traditional foods from South and West Sulawesi of Indonesia. This study has analyzed the effect of fish cooking methods and coconut maturity level on the sensory quality of the products produced. The effect of the treatment of grated coconut and the duration of the frying pan on the level of maturity of the tumpi product have also been studied. Reformulation of constituent materials and nutritional value of tuna tumpi products have been carried out. The results showed that the tumpi product made from grilled fish mixed with half-old coconut was the best product and the most preferred by consumers. Cooked tumpi or cooked perfectly product from grated Coconut not squeezed with a frying duration of 60-100 s are the products most preferred by consumers. The best composition of the ingredients for the best tuna tumpi products are 65\% fish, 15\% grated coconut, 5\% tapioca, and 15 seasoning. With serving size $100 \mathrm{~g}$, this product contribute 50\%, 18\% and 5\% Indonesian Recommended Daily Allowance for protein, fats, and carbohydrate, respectively, and release $277 \mathrm{cal}$.

Keywords: Fish Processing, Fish Tuna, Grated Coconut, Traditional Food, Tumpi Product

\section{INTRODUCTION}

Tumpi is one of the traditional foods of South and West Sulawesi (SULSELBAR) which has been known for a long time from generation to generation. This traditional food is made from a mixture of fish meat, grated coconut, flour, and seasoning. Fish commonly used are tuna, tuna, milkfish, tilapia, and others depending on the type of fish found in the area. This product is processed with simple methods and equipment, and is intended for activities related to the traditions of the local community, including religious activities, marriages, family gatherings, thanksgiving, and circumcisions. Even in some societies, assuming and believing that tumpi is a mandatory menu that must be made for the benefit of these activities. This is in accordance with that reported by Winarno et al. [40] that traditional food is a type of food that is very closely related to local phenomena, which is used as a tool to express love, a sign of friendship, and a symbol of social acceptance.

In some SULSELBAR regions, such as Mamuju, Majene, and Polman, these products are not only found in religious activities and customs, but have 
been produced and marketed. However, in urban areas, such as Makassar and its surroundings, tumpi products are rarely found. The development of food science and technology produces modern and instant foods, causing these products and similar traditional products to be of less interest. Almli et al [1] reported that the constraints in preparing traditional food products with specific tastes, quality, attractiveness, high nutritional value, healthy, and safe were long processing times and relatively expensive.

In addition, the younger generation is not interested in producing tumpi products because there are no documents that contain recipes, manufacturing procedures, and nutritional value of slime [2]. This also causes the products produced to be not uniform, varying from region to region, especially taste and appearance. Various studies are needed to overcome this problem. Previous research reported that the type of flour had an effect on the chemical characteristics and the level of sensory reception of the products of the tuna pudding [15]. Syahrul et al [37] also examined the optimization of coatings, frying temperature, and frying time of milkfish pudding.

These ingredients play an important role in the quality of tumpi products and help determine consumer preferences for the final product. The main ingredients of the tumpi product are fish and coconut. The binder ingredients of the tumpi product are flour. Additional ingredients for spring are seasoning. Fish species and fish preparation methods are believed to play an important role in the quality of tumpi products. The level of maturity and treatment of grated coconut is also thought to have a role in the acceptance of the tumpi products.

Likewise with the composition of the binder and herbs used. In this study, the researchers examined the effect of tuna cooking methods, coconut maturity level, and treatment of grated coconut as the main ingredients of tumpi production. In addition, the time of frying and the maturity level of tuna tumpi products are also studied. And finally, reformulation of constituent materials is carried out and studies the nutritional value of tuna tumpi. The use of tuna fish (Thunnus $s p$ ) in this study because this fish has a dense meat structure, contains high nutritional value, and high an edible portion. Characteristics of fish like that are suitable for producing nutritious and good quality tumpi products. The results of this study are expected to be one of the references for the younger generation to like the products of tumpi, so that they still exist as traditional foods. This study aims to evaluate and reformulate the ingredients of the tumpi product.

\section{METHODS AND MATERIAL}

\section{A. Material}

The main ingredients used in this study were tuna (Thunnus sp) Obtained from the Jakarta Muara Baru Fish Auction Place. Coconuts (Cocos nucifera L) and additional ingredients include seasoning (cereals, galangal, pepper powder, salt, lime, onion and cayenne pepper) obtained from traditional Bogor markets. The binding material (tapioca) and cooking oil were purchased from a supermarket in the city of Bogor.

\section{B. Seasoning Processing for Tumpi Products}

Spices are processed based on the composition that is often used by the community (reference field or emperies), namely $40 \%$ galangal, $25 \%$ red onion, $15 \%$ cereal, $10 \%$ chili, $5 \%$ pepper, and 5 salt. Milling and mixing of spices is done using a HK 7997 food processor.

\section{Determination of Fish Cooking methods and Coconut Maturity Level}

The stages of this research were carried out by producing tumpi from tuna fish and grated coconut. The composition of ingredients were used based on field references or empirically, namely $30 \%$ fish, $45 \%$ coconut, $10 \%$ tapioca, and $15 \%$ seasoning. The fish preparation methods were done by grilled and smoked. 
The maturity level of the coconut used were 1) young coconut, 2) half-old coconut, and 3) old coconut. Criteria for coconut maturity based on [16]. All ingredients were mixed until homogeneous, then printed in triangular shape with feet with a side length of approximately $\pm 4 \mathrm{~cm}$. Then fried in a deep fat frying method at a temperature of $160-180^{\circ} \mathrm{C}$. Then carried out sensory testing and determination of the best product.

\section{Determination of the Treatment of Grated Coconut and Time of Frying}

The stage of this study was to make tumpi products from grilled fish and half-old grated coconut. Composition of constituent materials and frying method used based on the previous stages (part C). The parameter that is the focus of the assessment at this stage is the treatment effect on grated coconut and frying time. The treatments performed on grated coconut were 1) squeezed once, 2) not squeezed, and 3 ) roasted. The products that produced were 1) precooked products, 2) cooked or cook perfectly products, and 3) over-cooked products. The criteria for precooked tumpi products are if the product has caused a distinctive aroma and has a light yellow color on the surface. The criteria product for cooked tumpi products are if the product has floated, the light yellow color turns yellow to brownish yellow, and smells distinctively sharper aroma. While the criteria for over-cooked tumpi products are if the brownish color of the product has begun to turn blackish brown and the aroma has begun to smell charred. The time used to produce the three products is an assessment parameter. All products were produced at the stage, as soon as they were removed from the frying kettle, they were placed immediately below the room temperature to stop the cooking process.

\section{E. Reformulation the Composition of the Tuna Tumpi Composite Material}

Field or emperies reference showed that the composition of the ingredients for the tumpi products were $30 \%$ fish, $45 \%$ coconut, $10 \%$ tapioca, and $15 \%$ seasoning. The composition of these main constituents (fish and coconut) and binder (tapioca) were reformulated. The percentage of the main ingredients increased to $80 \%$, the binder was reduced to $5 \%$, and the seasoning remained $15 \%$. The formulation is made in 5 products with a ratio between fish and grated coconut, namely $\geq 50 \%$ fish and $\leq 30 \%$ grated coconut. Product formulations are presented in Table 1. The aim of this reformulation was to produce better quality and chemical tumpi products.

\section{F. Sensory Analysis}

The sensory analysis used in this study is the hedonic test [30]. Hedonic test is a test method used to measure the level of preference for a food product by using a scale sheet of scale 1 to 9 . Tests are carried out by 30 non-standard panelists. Attributes that are assessed include, appearance, taste, color, aroma, taste, texture.

\section{G. Determination of the Best Products}

Determination of the best tumpi carried out based on the sensory test results using the Bayes method [19]. Bayes analysis is done by first ranking the importance index of the parameters observed according to the panelist's assessment. The parameters with the highest value in the Bayes method score five and the lowest score one. Value of importance for each parameter of this product, that is 1 if the parameter is not important, 2 if less important, 3 if normal, 4 if important, and 5 if very important. On average, the panelists consider the sensory parameters of tumpi products are important for aroma and texture and very important for appearance, flavor, and color atribute.

\section{H. Proximate analysis}

Water content analysis was carried out by the oven method [27]. The principle is to vaporize the free water molecules in the example. Analysis of ash content by the oven method [31]. The principle is the combustion or ignorance of organic materials which 
are broken down into water and carbon dioxide, but inorganic substances (ash) do not burn. Fat content analysis was carried out by the sokhlet method [28]. The principle is that the fat contained in the sample is extracted using non-polar fat solvents. Analysis of protein levels was carried out by the kjeldahl method [29]. The principle is carbon oxidation and the conversion of nitrogen to ammonia by sulfuric acid forms ammonium sulfate. Ammonium sulfate is made a base using $\mathrm{NaOH}$. Evaporated ammonia will be bound with boric acid. The amount of nitrogen contained in the solution is determined by titrating the acid solution. Carbohydrate level calculation is done using the method by difference [26].

\section{Data Analysis}

Sensory test results were processed using the KruskalWallis nonparametric test which aimed to find out whether between treatments differed significantly in ranking [33]. The treatment was significantly different, further tested by the Dunn method [6].

\section{RESULTS AND DISCUSSION}

\section{A. Determination of Fish Cooking methods and Coconut Maturity Level}

Tumpi products produced in this stage were presented in Fig 1. The Kruskal-Wallis test results showed that the method of cooking fish and the maturity level of coconut had a significant effect on the appearance, flavor, aroma, and texture of tuna tumpi products. The highest appearance value of tuna fish cone is achieved by I1K2 products and the lowest is achieved by product I1K1 (Table 2). The Dunn test results showed that the I1K2 product is significantly different from other tumpi products. This is due to the $11 \mathrm{k} 2$ product has more attractive color, bright, clean look, uniform surface, and irregular shape (fig 1). This is influenced by the water content of half-old coconut which is not too high and does not contain much oil, so that the formation of crust on the surface of the product occurs quickly and the capillaries formed are not large, it was produced products with smooth and even surface [21]. The appearance is also influenced by maillard reactions and fat oxidation [41].

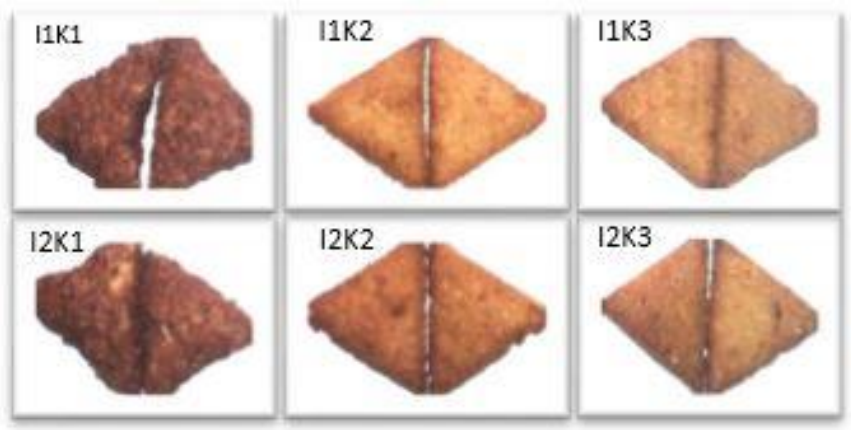

Figure 1. Tumpi products produced from grilled fish and smoked fish mixed young coconut, half-old coconut, and old coconut.

The highest flavor value achieved by I2K3 products and the lowest was achieved by I2K2 products (Table 2). The Dunn test results showed that I2K3 products were significantly different from other tumpi products. This is due to the I2K3 product has a savory taste compared to other tumpi products. The main source of taste is from spices used. In addition, this taste is thought to be formed because of the high fat content (coconut milk) in old coconut which is degraded by high temperatures. The taste also originated from smoked fish because of the presence of phenol and aldehyde compounds [26].

The highest aroma value of Tuna tumpi is achieved by I1 $\mathrm{K} 2$ products and the lowest is achieved by I2K1 products (Table 2). Dunn test results showed that the I1K2 and I2K3 products significantly different from other products. This is due to the distinctive aroma stronger in I1 $\mathrm{K} 2$ and $\mathrm{I} 2 \mathrm{~K} 3$ products. The aroma comes from volatile components due to the degradation of the content of coconut, fish, and seasoning when frying. Lin and Wilkens [18] reported that grated coconut meat will emit volatile components that are flavorful, delicious, and fragrant when subjected to 
processing at temperatures $70^{\circ} \mathrm{C}$. The aroma of this product is also produced from seasoning.

Table 1. Reformulation of the ingredients of tuna fish tumpi

\begin{tabular}{ccccc}
\hline \multirow{2}{*}{ Products } & \multicolumn{4}{c}{ Constituent material } \\
\cline { 2 - 5 } & $\begin{array}{c}\text { Tuna fish } \\
(\%)\end{array}$ & $\begin{array}{c}\text { Not squeezed grated coconut } \\
(\%)\end{array}$ & Tapioca (\%) & Seasoning (\%) \\
\hline A & 50 & 30 & 5 & 15 \\
B & 55 & 25 & 5 & 15 \\
C & 60 & 20 & 5 & 15 \\
D & 65 & 15 & 5 & 15 \\
E & 70 & 10 & 5 & 15 \\
F (control) & 30 & 45 & 10 & 15 \\
\hline
\end{tabular}

Table 2. Sensory assessment results of the determination of fish cooking methods and coconut maturity level

\begin{tabular}{clccr}
\hline \multirow{2}{*}{ Products code } & \multicolumn{3}{c}{ Sensory assessment parameters } \\
\cline { 2 - 5 } & Appearance & Flavor & Aroma & Texture \\
\hline I1K1 & $5,60 \pm 1,66^{\mathrm{a}}$ & $5,92 \pm 1,76^{\mathrm{a}}$ & $6,02 \pm 1,59^{\mathrm{a}}$ & $5,67 \pm 1,67^{\mathrm{a}}$ \\
I1K2 & $7,32 \pm 1,30^{\mathrm{d}}$ & $6,78 \pm 1,04^{\mathrm{b}}$ & $6,93 \pm 0,97^{\mathrm{b}}$ & $6,67 \pm 1,42^{\mathrm{b}}$ \\
I1K3 & $6,70 \pm 0,96^{\mathrm{c}}$ & $6,25 \pm 1,36^{\mathrm{a}}$ & $6,55 \pm 1,13^{\mathrm{a}}$ & $6,58 \pm 1,33^{\mathrm{b}}$ \\
I2K1 & $5,62 \pm 1,51^{\mathrm{a}}$ & $6,03 \pm 1,62^{\mathrm{a}}$ & $5,93 \pm 1,70^{\mathrm{a}}$ & $5,72 \pm 1,72^{\mathrm{a}}$ \\
I2K2 & $5,93 \pm 1,44^{\mathrm{a}}$ & $5,09 \pm 1,68^{\mathrm{a}}$ & $6,57 \pm 1,25^{\mathrm{a}}$ & $5,93 \pm 1,55^{\mathrm{a}}$ \\
I2K3 & $6,35 \pm 1,61^{\mathrm{b}}$ & $6,90 \pm 1,07^{\mathrm{c}}$ & $6,70 \pm 1,14^{\mathrm{b}}$ & $6,80 \pm 1,39^{\mathrm{b}}$ \\
\hline
\end{tabular}

Numbers in the same column followed by different superscript letters (a, b, c, d) showed significantly different $(\mathrm{p}<0.05)$.

$\mathrm{I} 1 \mathrm{~K} 1$ = grilled fish+young coconut, $\mathrm{I} 1 \mathrm{~K} 2=$ grilled fish+half-old coconut, I1 K3= grilled fish+old coconut, I2K1= smoked fish+young coconut, I2K2= smoked fish+half-old coconut, I2K3= smoked fish+old coconut.

Table 3. Bayes analisys method of the determination of fish cooking methods and coconut maturity level

\begin{tabular}{|c|c|c|c|c|c|c|c|}
\hline \multirow{2}{*}{ Parameters } & \multicolumn{6}{|c|}{ Products code } & \multirow{2}{*}{$\begin{array}{l}\text { Bobot } \\
\text { value }\end{array}$} \\
\hline & I1 K1 & I1 K2 & I1 K3 & I2K1 & $\mathrm{I} 2 \mathrm{~K} 2$ & I2K3 & \\
\hline Flavor & 2 & 5 & 4 & 3 & 1 & 6 & 0,286 \\
\hline Appearance & 1 & 6 & 5 & 2 & 3 & 4 & 0,286 \\
\hline Texture & 1 & 5 & 4 & 2 & 3 & 6 & 0,229 \\
\hline Aroma & 2 & 6 & 3 & 1 & 4 & 5 & 0,200 \\
\hline total value & 3,3 & 10,5 & 6,7 & 3,1 & 6,0 & 9,4 & \multirow{2}{*}{1,000} \\
\hline Rangking & 5 & 1 & 3 & 6 & 4 & 2 & \\
\hline
\end{tabular}

The highest texture value of Tuna is achieved by I2K3 products and the lowest is achieved by product $\mathrm{I} 1 \mathrm{~K} 1$ (Table 2). The Dunn test results showed that the I2K3 product was not significantly different from I1K2 and I1K3 products, but was significantly different from the $\mathrm{I} 1 \mathrm{~K} 1, \mathrm{I} 2 \mathrm{~K} 1$, and I2K2 product. The I2K3, I1K2, and 
I1K3 product were preferred because it has a rather dense texture, but not too hard. The texture was formed because the water content of the half-old coconut and the old coconut is not too high compared to the young coconut. Evaporation of water when the frying produces a rather dense structure and good crust. Muchtadi and Ayustaningwarno [23] explained that food texture changes during frying, which will improve the quality of eating quality due to the formation of crispy crust on the surface of food. Denaturation and coagulation of proteins that occur due to heat also affect the texture of food. Gerrard [11] reported that maillard reactions affect the formation of texture and digestibility food through cross-linking proteins.

Tumpi made from young coconut has a soft and clayy texture, so it is less liked by panelists. Soft and clayy texture is formed by physicochemical properties of young coconut which contain high galactomannan and low protein. Barlina [3] reported that young coconuts contain high galactomannan, so that they are only suitable for processing for semi-solid products that require a chewy or soft texture. Galactomannan is a polysaccharide that is almost entirely dissolved in water, which forms a thick solution and gel.

The results of Bayes analysis (Table 3 ) showed that the I1K2 tuna tumpi product has the highest total value or rank 1, which indicated that tuna tumpi made from grilled fish and half-old coconut was the best product. So, grilled fish and half-old coconut will be used in the next test.

\section{A. Determination of the Treatment of Grated Coconut and Time of Frying}

The treatment of grated coconut affects the frying time for each product maturity level were presented in Table 4. The time frying of precooked tumpi $(\mathrm{K} 1 \mathrm{t} 1$, $\mathrm{K} 2 \mathrm{t} 1, \mathrm{~K} 3 \mathrm{t} 1)$, cooked tumpi (K1t2, K2t2, K3t2), and overcooked tumpi (K1t3, K2t3, K3t3) products were 45-60 s, 60-100 s, and 90-150 s, respectively. The product will be precooked if it produces a distinctive aroma and has a light yellow color on the surface. K1t1 and $\mathrm{K} 1 \mathrm{t} 3$ products have the same of frying time, which is between $45-60 \mathrm{~s}$, about $5 \mathrm{~s}$ faster reaching the precooked condition of the K1t2 product, which has a frying time of between 55-60 s. All precooked tumpi products will immediately cook perfectly after arriving at the $60^{\text {th }} \mathrm{s}$, characterized by products that floats and turns light yellow color to yellow to golden brown and formed a tumpi distinctive aroma. Budzaki and Seruga [5] reported that evaporation of water when food frying occurs in two periods, in the first 60 $s$ the water loss more intensive and in the period after $60 \mathrm{~s}$ until $120 \mathrm{~s}$ the water loss was constant.

All cooked tumpi products have the same in precooked tumpi, but different in long times maturity. The K2t3 product has a faster cooked condition in the $90^{\text {th }} \mathrm{s}, \mathrm{K} 2 \mathrm{t} 1$ in the $95^{\text {th }} \mathrm{s}$, and the $\mathrm{K} 2 \mathrm{t} 2$ product in the $100^{\text {th }} \mathrm{s}$. The cooked tumpi product turns into overcooked tumpi when the brownish yellow color has begun to turn blackish brown and the aroma has begun to smell charred. Overcooked tumpi that have different initial time overcooked also have different end times. All overcooked tumpi products will be forfeited if they pass the old frying pan.

The results of the Kruskal-Wallis test showed that the treatment carried out on grated coconut had a significant effect on the appearance, taste, color, aroma, and texture of the pile product (Tables 4). Tumpi products produced in this research stage were presented in Fig 2. The highest and lowest appearance values of the tumpi products are K2t2 and K1t3. The Dunn test results showed that the tumpi K2t2 product was not significantly different from the tumpi K1t2 product, but was significantly different from other products. This is due to the fact that tumpi $\mathrm{K} 2 \mathrm{t} 2$ and K1t2 made from grated coconut are not squeezed but still contain enough water, so the mixture mixes well 
and blends together, forming a compact and solid bond [35]. Homogeneous dough produces a neat and evenly distributed product. Evaporation of water causes the product structure to be more compact, mutually integrated and dense (fig 2). Uniformity of shape and flat surface is damaged if the frying time is extended, as happened in overcooked tumpi products from grated coconut without squeezed (K3t2).

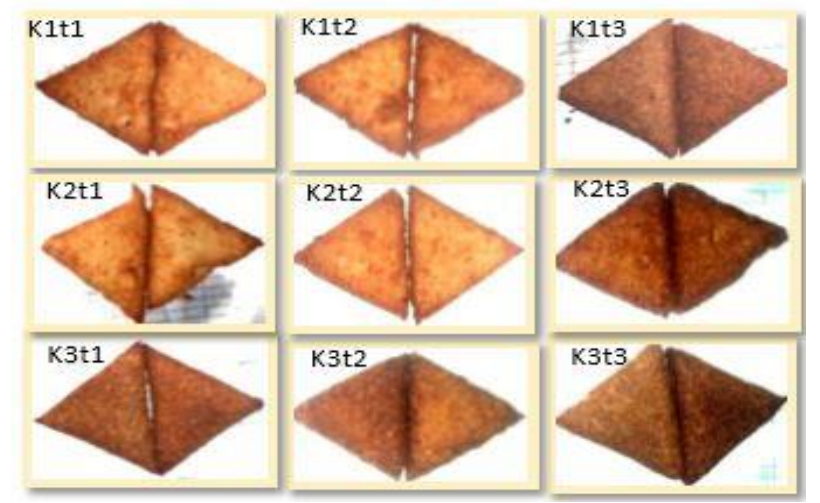

Figure 1. Tumpi products produced from grilled fish mixed with grated half-old coconut are squeezed once, not squeezed, and roasted.

The highest and lowest color values of the tumpi products are K2t2 and K3t3 (Tables 4). The Dunn test results showed that the color of the tumpi K2t2 product was not significantly different from the tumpi K1t1 product, but was significantly different from other products. This is due to the K2t2 and K1t1 products have more attractive color than the other tumpi products. This attractive color results from maillard reaction and fat oxidation during frying.

The reaction between amino acids and sugar forms a bright yellow to brownish yellow on the outside of the product $[41 ; 22]$. The color brightness of the product decreases due to the subsequent browning reaction of Kumar et al [17]. This means that the higher the temperature and the longer the frying time, food products are increasingly disliked by panelists. The color of the product is also caused by fat oxidation which occurs because high temperatures and free oxygen around the frying kettle produce a brownish yellow color, such as the K2t2 and K1t1 products. Both non-enzymatic browning reactions continue, if the time is extended and the temperature is still high, even this process still occurs even though the product has been removed from the frying pan if the temperature is still high. This process indicates a decrease in the quality of the sensory, chemical, and eating quality of the product, as happened in overcooked products.

All tumpi products from coconut roaster and overcooked products have a brown color and are rather dark. This causes the level of panelists' assessment of the colors of these products to be on average low. The brown and rather dark color of the product made from roasted coconut is caused by the color of coconut roaster. Coconut roasted has undergone a browning process during the roasting process, when fried the product undergoes further browning. This means that this product has browned for a long time. This browning process also occurs in overcooked pile products.

The highest and lowest flavor values of the tumpi products were K2t2 and K3t3 (Tables 4). The Dunn test results show that the tumpi $\mathrm{K} 2 \mathrm{t} 2$ product is significantly different from other tumpi products. This is because grated coconut without squeezing has a high content of coconut milk. The coconut milk content breaks down when the frying process becomes a non-volatile component which gives a distinctive taste of coconut $[18 ; 39]$. The taste of the tumpi product is also caused by the addition of seasoning. Galangal and citronella leaves have physicochemical properties as an essential oil for flavor and aroma. The flavor formation was also produced by the maillard reaction and fat oxidation during frying. Zamora and Francisco [41] reported that the stage of taste formation in the maillard reaction and fat oxidation occurs in the second stage of the reaction. The first stage forms amadori (1-amino-1-deoxy-2-ketosa) and hydroperoxide. These nonvolatile components play a role in the taste of fried products. 
The highest and lowest aroma value of tumpi products were K2t2 and K3t3 (Tables 4). The Dunn test results showed that the $\mathrm{K} 2 \mathrm{t} 2$ tumpi product is not significantly different from the K1t1 product, K1t2 product, and the $\mathrm{K} 2 \mathrm{t} 1$ tumpi product, but is significantly different from other tumpi products. The preference of panelists on K2t2, K1t1, K1t2, and K2t products is due to the fact that grated coconut still contains a lot of coconut milk, so the formation of volatile components when frying takes place is very high, unlike roasted coconut which has lost coconut milk when preparing. Coconut fat (coconut) began coagulated at a temperature of $80{ }^{\circ} \mathrm{C}$ produces a distinctive aroma [39]. Lin and Wilkens [18] and Jirapong et al. [14] reported that volatile compounds evaporate and produce a distinctive aroma if the heated coconut milk is 9-octadecenoic acid, ethyl octanoate, $\delta$-C8-laktone, ethyl decanoate, $\delta$-C10laktone, and n-octanol. These components synergize with spices to produce a fragrant aroma when frying
The highest and lowest texture values of the tumpi products were $\mathrm{K} 2 \mathrm{t} 2$ and $\mathrm{K} 2 \mathrm{t} 1$ (Tables 4 ). The Dunn test results showed that the tumpi K2t2 product is significantly different from other products. This is due to the fact that the K2t2 product has a more compact, dense, and rather hard texture and has regular cracks on the surface when pressed with a finger. This texture is formed when stirring the mixture. Grated coconut that is not squeezed still contains enough water, making it easier for the mixture to mix evenly. Dissolved proteins (actin, myosin, and actomyosin) from fish form dough that is compact and fused together, so that the surface of the product appears smoother, evenly distributed, and crispy crust [35]. Crispness causes the surface of the product to crack when under pressure. Martin et al [20] reported that the crisp texture of fried food products is characterized by regular fragility when bitten or given a little pressure.

Table 4. Results of sensory analysis and time prying tumpi products produced from grilled fish mixed with grated half-old coconut are squeezed once, not squeezed, and roasted

\begin{tabular}{ccccccc}
\hline Products & frying & \multicolumn{5}{c}{ Sensory attribute } \\
\cline { 3 - 7 } code & duration $(\mathrm{s})$ & Appearance & Flavor & Color & Aroma & Texture \\
\hline K1t1 & $45-60$ & $6,68 \pm 1,20^{\mathrm{c}}$ & $6,67 \pm 1,08^{\mathrm{c}}$ & $7,05 \pm 1,03^{\mathrm{d}}$ & $6,83 \pm 1,01^{\mathrm{d}}$ & $6,72 \pm 0,85^{\mathrm{d}}$ \\
K1t2 & $60-95$ & $6,80 \pm 1,19^{\mathrm{d}}$ & $6,63 \pm 1,01^{\mathrm{c}}$ & $6,47 \pm 1,19^{\mathrm{c}}$ & $6,78 \pm 0,76^{\mathrm{d}}$ & $6,65 \pm 0,88^{\mathrm{c}}$ \\
K1t3 & $95-140$ & $5,65 \pm 1,36^{\mathrm{a}}$ & $6,28 \pm 1,32^{\mathrm{a}}$ & $5,68 \pm 1,40^{\mathrm{a}}$ & $6,15 \pm 1,05^{\mathrm{b}}$ & $6,07 \pm 1,19^{\mathrm{a}}$ \\
K2t1 & $55-60$ & $6,32 \pm 1,21^{\mathrm{b}}$ & $6,65 \pm 0,92^{\mathrm{c}}$ & $6,03 \pm 1,39^{\mathrm{b}}$ & $6,98 \pm 1,23^{\mathrm{d}}$ & $5,97 \pm 1,23^{\mathrm{a}}$ \\
K2t2 & $60-100$ & $7,18 \pm 1,10^{\mathrm{d}}$ & $7,07 \pm 0,80^{\mathrm{d}}$ & $7,22 \pm 1,03^{\mathrm{d}}$ & $7,03 \pm 0,90^{\mathrm{d}}$ & $7,08 \pm 0,94^{\mathrm{e}}$ \\
K2t3 & $100-150$ & $5,77 \pm 1,87^{\mathrm{a}}$ & $6,50 \pm 1,17^{\mathrm{b}}$ & $5,37 \pm 1,41^{\mathrm{a}}$ & $6,08 \pm 1,37^{\mathrm{b}}$ & $6,45 \pm 1,29^{\mathrm{b}}$ \\
K3t1 & $45-60$ & $5,88 \pm 1,37^{\mathrm{a}}$ & $6,60 \pm 1,01^{\mathrm{b}}$ & $5,75 \pm 1,41^{\mathrm{a}}$ & $6,25 \pm 1,37^{\mathrm{c}}$ & $6,33 \pm 1,17^{\mathrm{a}}$ \\
K3t2 & $60-90$ & $5,75 \pm 1,27^{\mathrm{a}}$ & $6,30 \pm 1,00^{\mathrm{a}}$ & $5,57 \pm 1,38^{\mathrm{a}}$ & $5,97 \pm 1,31^{\mathrm{a}}$ & $6,22 \pm 1,40^{\mathrm{a}}$ \\
K3t3 & $90-140$ & $5,57 \pm 1,57^{\mathrm{a}}$ & $5,83 \pm 1,20^{\mathrm{a}}$ & $5,33 \pm 1,51^{\mathrm{a}}$ & $5,58 \pm 1,34^{\mathrm{a}}$ & $6,15 \pm 1,25^{\mathrm{a}}$ \\
\hline
\end{tabular}

The numbers in the same column followed by different superscript letters (a, b, c, d, e) showed significantly different $(\mathrm{p}<0.05)$

$\mathrm{K} 1 \mathrm{t} 1=$ pre-cooked tumpi made from squeezed once grated coconut; $\mathrm{K} 1 \mathrm{t} 2=$ cooked tumpi made from squeezed once grated coconut ; K1t3 = over-cooked tumpi made squeezed once grated coconut; $\mathrm{K} 2 \mathrm{t} 1$ = pre-cooked tumpi made from not squeezed grated coconut; K2t2 = cooked tumpi made from not squeezed grated coconut; $\mathrm{K} 2 \mathrm{t} 3$ = over-cooked tumpi made from not squeezed grated coconut; K3t1 = pre-cooked cooked made from 
roasted coconut; $\mathrm{K} 3 \mathrm{t} 2$ = cooked tumpi made from roasted coconut; $\mathrm{K} 3 \mathrm{t} 3=$ over-cooked tumpi made from roasted coconut.

The results of the Bayes analysis (Table 5) show that the K2t2 product has the highest value of 8.28, so it is in rank I. This means that cooked tumpi or cook perfectly products from no squeezed grated coconut was the best product. Therefore, cooked tumpi from grated coconut is not squeezed with the length of duration the frying pan between 60-100 seconds will be used for the next stage.

Table 5. Bayes analysis results of tumpi products produced from grilled fish mixed with grated half-old coconut are squeezed once, not squeezed, and roasted

\begin{tabular}{lccccccccccc}
\hline \multirow{1}{*}{$\begin{array}{c}\text { Sensory } \\
\text { attribute }\end{array}$} & \multicolumn{10}{c}{ Products code } & \multirow{2}{*}{ Bobot value } \\
\cline { 2 - 10 } & K1t1 & K1t2 & K1t3 & K2t1 & K2t2 & K2t3 & K3t1 & K3t2 & K3t3 & \\
\hline Appearance & 7 & 8 & 1 & 6 & 9 & 3 & 5 & 2 & 4 & 0.23 \\
Flavor & 8 & 6 & 2 & 7 & 9 & 4 & 5 & 3 & 1 & 0.23 \\
Color & 6 & 8 & 7 & 4 & 5 & 9 & 2 & 3 & 1 & 0.18 \\
Aroma & 7 & 6 & 5 & 8 & 9 & 2 & 4 & 2 & 1 & 0.18 \\
Texture & 8 & 7 & 2 & 1 & 9 & 6 & 5 & 4 & 3 & 0.18 \\
\hline Total value & 7.2 & 7.0 & 3.2 & 5.3 & 8.3 & 4.7 & 4.3 & 2.7 & 2.1 & \multirow{2}{*}{1.00} \\
Rangking & 2 & 3 & 7 & 4 & 1 & 5 & 6 & 8 & 9 & \\
\hline
\end{tabular}

\section{B. Reformulation the Composition of the Tuna Tumpi Composite Material}

The tumpi product produced from this new formulation were presented in fig 3 and were tested for its sensory properties to find the best product (Table 6). The results of the Kruskal-Wallis test showed that an increase in the percentage of fish and a reduction in the amount of grated coconut had a significant effect on the appearance, flavor, color, aroma, and texture of the product. Tumpi printing is made in uniform shapes and sizes, which are triangular in shape with sides, with sides of $\pm 4 \mathrm{~cm}$. The shape and size of the product undergoes changes during the frying process. Changes in the shape and size of each product vary based on the composition of the main constituent material.

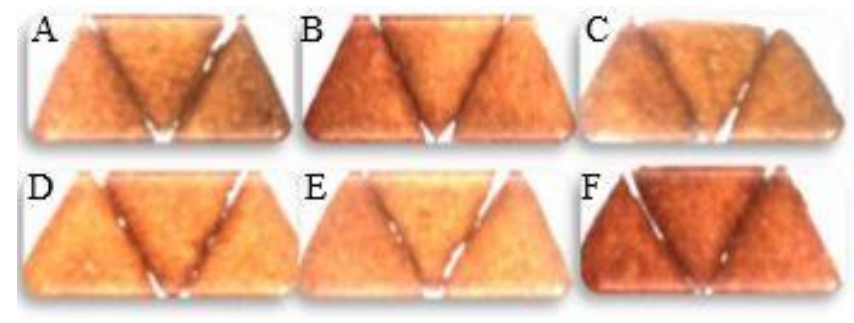

Figure 3. Tumpi products produced from reformulation of constituent materials.
The appearance value of the tumpi product increases in every addition of 5-10\% of fish and decreases in 5$10 \%$ of grated coconut (Table 6). This is due to the increase in the number of fish causing an increase in the amount of protein in the product. Protein has the ability to bind a certain amount of water, so that evaporation when frying is not too large. Dogan et al. [8] reported that the addition of raw materials with high protein content can reduce the loss of water content of fried products. Low evaporation of water in the outer laye and crust (outer zone surface) can reduce shrinkage of the product structure. Garayo and Moreira [10] suggested that the more water evaporates, the greater the shrinkage volume. Uneven shrinkage produces a non-uniform, dull, rough and wavy surface. The inner zone of the product forms an air cavity resulting in a somewhat convex surface of the product. Bonded water molecules in the material structure give rise to vapor pressure, which results in 
the inner zone of the product expanding following the boundary of the outer zone. This convex shape will decrease with decreasing temperature, which affects the appearance of the product. The appearance of products can be seen in fig 3 .

Products that have the highest and lowest color values were D and A (Table 6). The Dunn test results showed that the $\mathrm{D}$ product was not significantly different from the E product, but was significantly different from the $\mathrm{A}, \mathrm{B}, \mathrm{C}$, and $\mathrm{F}$ (control) products. This is due to the fact that the $\mathrm{D}$ and $\mathrm{E}$ products have a bright yellow color and look clean (fig 3). The color is produced by the maillard reaction when frying. Ndife et al [24] reported that the maillard reaction was caused by the reaction of soy protein with sugar during the roasting process. Fish proteins were denatured into amino acids and carbohydrates into reducing and non-reducing sugars. The nucleophilic groups of amino acids react with carbonyl groups from reducing sugars which produce melanoidin compounds.

Zamora and Hidalgo [41] reported that the reaction between amino acids and reducing sugars was the first stage reaction in the maillard reaction to produce $N$ substituted glycosylamine. Furthermore, the compound undergoes an amadory reaction to produce 1-amino-1-dioxy-2-ketose. The second stage of the reaction are dehydration, fragmentation, enolization, and stecker degradation of sugar to produce volatile and non-volatile components. The third stage of the reaction is condensation of volatile components and polymerization of non-volatile components to produce a bright brown color.

Products that have the highest and lowest flavor values were $\mathrm{F}$ and $\mathrm{C}$ (Table 6). The Dunn test results showed that the $\mathrm{F}$ product was significantly different from other tumpi products. This means that the control products have a taste more delicious than the product which has increased the number of fish and decrease the amount of grated coconut. The panelist likes the tumpi product with high grated coconut content. Grated coconut contains coconut milk and high water which produces a distinctive taste and aroma [32; 7]. The habit of panelists consuming tumpi products with high coconut composition is still influential in sensory testing.

Products that have the highest and lowest aroma values were $\mathrm{E}$ and A (Table 6). The Dunn test results show that $\mathrm{E}$ products was significantly different from other tumpi products. Panelists really like E products due to the high percentage of fish. Amino acids that react with reducing sugars when frying produce 1amino-1-deoxy-2-ketose (Zamora and Hidalgo 2005). The next reaction produces volatile components containing oxygen and nitrogen which play a role in forming a distinctive aroma. Aroma compounds containing oxygen include 2,3-utanedione, 2,3pentanedione, methylpropanal, 3-methylbutanal, phenylacetal-dehyde, 3-hydroxy-4,5-dimethyl-2 (3H) -furanone, and 2, 5-dimethyl-4-hydroxy-3 (2H) furanone. Whereas, aroma compounds containing nitrogen include 2-ethyl-3,5-dimethylpyrazine, 2,3diethyl-5-methylpyrazine, and 2-acetyl-1-pyrroline. This component synergizes with seasoning to produce a distinctive aroma of tumpi products.

Table 6 shows that an increase in the amount of fish meat and a decrease in the amount of grated coconut are positively correlated with the level of panelists' assessment of the aroma of tumpi products. Each addition of $5 \%$ of fish and a decrease of $5 \%$ of grated coconut, resulting in the level of preference of panelists also increased. This is due to tuna meat has a distinctive aroma when heated. 
Table 6. Sensory assessment results of reformulation the composition of the tuna tumpi composite material

\begin{tabular}{cccccc}
\hline \multirow{2}{*}{ Products code } & \multicolumn{5}{c}{ Sensory assessment parameters } \\
\cline { 2 - 6 } & Appearance & Flavor & Color & Aroma & Texture \\
\hline A & $5,63 \pm 1,18^{\mathrm{a}}$ & $6,50 \pm 0,91^{\mathrm{a}}$ & $5,92 \pm 1,33^{\mathrm{a}}$ & $6,42 \pm 1,16^{\mathrm{a}}$ & $6,24 \pm 1,14^{\mathrm{a}}$ \\
B & $6,49 \pm 0,95^{\mathrm{c}}$ & $6,60 \pm 0,85^{\mathrm{a}}$ & $6,64 \pm 1,13^{\mathrm{b}}$ & $6,56 \pm 1,08^{\mathrm{a}}$ & $6,46 \pm 1,21^{\mathrm{a}}$ \\
C & $6,44 \pm 0,78^{\mathrm{c}}$ & $6,31 \pm 1,25^{\mathrm{a}}$ & $6,32 \pm 1,18^{\mathrm{a}}$ & $6,75 \pm 0,74^{\mathrm{b}}$ & $6,83 \pm 0,93^{\mathrm{b}}$ \\
D & $7,23 \pm 0,77^{\mathrm{d}}$ & $6,96 \pm 0,90^{\mathrm{b}}$ & $7,24 \pm 0,89^{\mathrm{c}}$ & $7,02 \pm 0,76^{\mathrm{c}}$ & $7,04 \pm 0,91^{\mathrm{c}}$ \\
E & $7,25 \pm 0,94^{\mathrm{d}}$ & $6,91 \pm 1,01^{\mathrm{b}}$ & $7,16 \pm 1,02^{\mathrm{c}}$ & $7,25 \pm 0,79^{\mathrm{d}}$ & $6,79 \pm 0,93^{\mathrm{b}}$ \\
F & $6,16 \pm 0,12^{\mathrm{b}}$ & $7,18 \pm 0,91^{\mathrm{c}}$ & $6,37 \pm 1,14^{\mathrm{a}}$ & $6,66 \pm 1,01^{\mathrm{a}}$ & $6,47 \pm 0,94^{\mathrm{a}}$ \\
\hline
\end{tabular}

The numbers in the same column followed by different superscript letters ( $a, b, c, d)$ showed significantly different $(\mathrm{p}<0.05)$

Table 7. Bayes analysis results of reformulation the composition of the tuna tumpi composite material.

\begin{tabular}{|c|c|c|c|c|c|c|c|}
\hline \multirow{2}{*}{ Parameters } & \multicolumn{6}{|c|}{ Products code } & \multirow{2}{*}{ Bobot value } \\
\hline & A & $\mathrm{B}$ & $\mathrm{C}$ & $\mathrm{D}$ & $\mathrm{E}$ & $\mathrm{F}$ & \\
\hline Appearance & 1 & 4 & 3 & 5 & 6 & 2 & 0,22 \\
\hline Flavor & 2 & 3 & 1 & 5 & 4 & 6 & 0,22 \\
\hline Color & 1 & 2 & 4 & 6 & 5 & 3 & 0,22 \\
\hline Aroma & 1 & 2 & 4 & 5 & 6 & 3 & 0,17 \\
\hline Texture & 1 & 2 & 5 & 6 & 4 & 3 & 0,17 \\
\hline Total value & 1,2 & 2,7 & 3,3 & 5,4 & 5,0 & 3,4 & \multirow{2}{*}{1,00} \\
\hline Rangking & 6 & 5 & 4 & 1 & 2 & 3 & \\
\hline
\end{tabular}

Tumpi products that have the highest and lowest texture values were D and A (Table 6). The Dunn test results showed that the $\mathrm{D}$ product was significantly different from other tumpi products. The favorite of panelists in the $\mathrm{D}$ product was influenced by the texture of the product that is more compact, soft, rather dense, rather hard, and has regular cracks on the surface when pressed with the finger. The texture is formed by evaporation of water followed by the hardening of the product structure when frying. Proteins and fats can bind a number of water to produce a material structure that is compact, dense, rather hard, and crisp on the surface after experiencing frying processes. Gerrard [11] reported that maillard reactions affect the formation of fried products' texture and digestibility through cross-linking of proteins. Besides, high temperature causes the cellular structure and sub-cellular structure of the product to change due to starch gelatinization. This change in structure causes the texture of the product to be tight, hard and elastic.

The results of the Bayes analysis of the sensory value of the product are presented in Table 7. The D tumpi products have the highest total value or rank I, so that it becomes the best product as a result of reformulation of constituent materials. This means that tumpi products made from $65 \%$ fish, $15 \%$ grated coconut, $5 \%$ tapioca, and $15 \%$ seasoning are the products most preferred by consumers. Furthermore, this product is analyzed proximate and calculated nutritional value.

\section{Chemical Characteristics and Nutritional Value of the Best Tuna Tumpi}

The chemical characteristics of the best tumpi products produced by reformulating the constituent material were presented in Table 8 . The level of water and protein of the tumpi product is influenced by several factors, including roasting fish meat, increasing 
the number of fish, decreasing the amount of grated coconut, and the frying process. The method of cooking with roasting causes the water content of fish to evaporate [12]. The temperature and time of frying also affect the product moisture content. Budsaki and Seruga [5] reported that the higher the temperature and the length of the frying time, the greater the water that evaporates. The use of larger fish meat $(65 \%)$ is the main source of high levels of tuna products. Erkan et al [9] explained that the increase in protein levels of several types of marine fish was influenced by the initial protein levels of fish and cooking methods. Cooking method produces the highest protein content are deep fat frying and roasting. Gokoglu et al [12] reported that the amount of water loss due to frying causes concentrated fish protein.

Most of the fat content of tumpi products comes from frying media and only a small part of the raw material because the use of grated coconut as a source of fat has been reduced to $15 \%$. Budzaki and Seruga [5] reported

Table 8. Chemical characteristics and nutritional value of the best tuna tumpi in three consumer groups

\begin{tabular}{lccccccc}
\hline Biochemical & Contents & \multicolumn{2}{c}{ Adults } & Children (2-5 year old) & \multicolumn{2}{c}{ Pregnant womens } \\
\cline { 3 - 7 } \multicolumn{1}{c}{$(\%)$} & RDAperties & $(\mathrm{g}) *$ & $\%$ NAR & RDA $(\mathrm{g}) *$ & \% NAR & RDA $(\mathrm{g}) *$ & $\%$ NAR \\
\hline Water & $42,91 \pm 0,46$ & - & - & - & - & - & - \\
Ash & $2,13 \pm 0,11$ & - & - & - & - & - & - \\
Fat & $11,46 \pm 0,77$ & 62 & 18 & 40 & 29 & 60 & 19 \\
Carbohydrate & $13,79 \pm 0,12$ & 300 & 5 & 200 & 7 & 320 & 4 \\
Protein & $29,71 \pm 0,40$ & 60 & 50 & 35 & 85 & 81 & 37 \\
Energy total & $277(\mathrm{cal})$ & $2000(\mathrm{cal})$ & 14 & $1300(\mathrm{cal})$ & 21 & $2160(\mathrm{cal})$ & 13 \\
\hline
\end{tabular}

* Recommended Daily Allowance based on the references of the food products nutritional label (BPOM 2007): NAR; nutrition adequacy rate

Nutritional Adequacy Rate (RDA) is an average daily nutrient sufficiency value for all people according to age group, gender, body size, body activity and physiological conditions to achieve optimal health status. Calculation of the percentage of RDA begins with determining the serving size based on the energy needs of adults, namely 2000-2200 cal. As many as 1400 calories of daily needs for adults are obtained from 3 times the consumption of staple foods, namely breakfast, lunch, and dinner, 400, 500, and $500 \mathrm{cal}$,

that evaporation of water from the product during frying followed by the absorption of oil into the product through the pores left by water. The carbohydrate content of the tumpi is influenced by binder and grated coconut. Suhardi and Bonimin [34] reported that adding 5 and 10\% tapioca can increase the carbohydrate content of corn starch products. Grated coconut also has carbohydrate levels of around $10-13.11 \%$ [13].

The ash content tumpi products was affected by the processing process. The content of the mixture of ash products is affected by the processing process. Santoso et al [25] reported the mineral content of food can experience chemical changes during the processing, after processing, and interactions between components of constituent materials. Erkan et al [9] reported that the ash content of some marine fish increased after frying and roasting. respectively. The remaining $600-800$ cal can be fulfilled by consuming snacks or snacks. Snacks or snack foods can be consumed 3-4 times a day, each consumption is expected to meet the daily needs of around 160-180 calories. Tumpi product can be consumed as a snack. Thus, by serving size 100 grams can meet the daily needs of adults for protein, fat, carbohydrates, and total energy of $50 \%$ of $60 \mathrm{~g} /$ day, $18 \%$ of $62 \mathrm{~g} /$ day, $5 \%$ of $300 \mathrm{~g} /$ day, and $14 \%$ of $2000 \mathrm{cal} /$ day, 
respectively (Table 8). Tumpi products are suitable for consumption by children aged 2-5 years who are lazy to eat because they can meet the daily needs of protein, fat, carbohydrate, and toll energy of $85 \%$ of $35 \mathrm{~g} /$ day, $29 \%$ of $40 \mathrm{~g} /$ day, $7 \%$ of $200 \mathrm{~g} /$ day, and $21 \%$ of 1300 $\mathrm{cal} /$ day, respectively (Table 8 ). This product can also meet the daily needs of pregnant women for protein, protein, fat, carbohydrate, and total energy of $37 \%$ of $81 \mathrm{~g} /$ day, $19 \%$ of $60 \mathrm{~g} /$ day, $4 \%$ carbohydrate of 320 $\mathrm{g} /$ day, and $14 \%$ of $2160 \mathrm{cal} /$ day, respectively (Table 8 ).

Tumpi products can be claimed as a food source of protein because they have a protein content of $\geq 20 \%$ ALG per $100 \mathrm{~g}$, but cannot be claimed as high protein food because they contain protein $\leq 35 \%$ per $100 \mathrm{~g}$. This product also does not include low-fat and low-calorie foods because it contains $>3 \% / 100 \mathrm{~g}$ fat and calories $>40 \mathrm{cal} / 100 \mathrm{~g}[4]$.

\section{IV.CONCLUSION}

The best tuna tumpi product is cooked tumpi or cook perfectly made from half-old coconut without squeezing and grilled fish. The time of deep fat frying needed to produce the best tuna tumpi is between 60-100 s. The best tuna tumpi from reformulation of ingridients materials is D product, which is the formulation of $65 \%$ fish, $15 \%$ coconut, $5 \%$ tapioca, and $15 \%$ seasoning. The nutritional value of tumpi $\mathrm{D}$ can meet the daily nutritional needs of an adult's body of protein, fat, and carbohydrate, and energy, 50\%, 18\%, 5\%, $277 \mathrm{cal}$, respectively.

\section{AKNOLEGEMENT}

The authors would like to thank Dr. Winni Trilaksani and Dr. Ruddy Suwandi, Department of Aquatic Products Technology, Bogor Agricultural University, for their support, supervision and guidance during this research was conducted.

\section{REFERENCES}

[1]. Almli VL, Verbeke W, Vanhonacker F, Næs T, Hersleth M. 2011. General image and attribute perceptions of traditional food in six European countries. Food Quality and Preference 22:129138.

[2]. Arismunandar NE. 28 Sept 2010. 100 Jenis Makanan di Festival Kuliner Sulawesi Selatan. Tempo.com.

[3]. Barlina R. 2004. Potensi buah kelapa muda untuk kesehatan dan pengolahannya. Perspektif, 3(2):46-60.

[4]. BPOM] Badan Pengawas Obat dan Makanan. 2011. Peraturan kepala badan pengawas obat dan makanan republik Indonesia nomor HK.03.1.23.11.11.09909 tentang pengawasan klaim dalam label dan iklan pangan olahan.

[5]. Budzaki S, Seruga B. 2005. Moisture loss and oil uptake during deep fat frying of krostula dough. European Food Research Technology. 220:90-95.

[6]. Daniel WW. 1990. Applied Non Parametric Statistics. PWS-Kent Publishing Company.

[7]. [DMPPIPT] Deputi Menegristek Bidang Pendayagunaan dan Pemasyarakatan Ilmu Pengetahuan dan Teknologi. 2001. Minyak Kelapa. Teknologi Tepat Guna. DPPPIPT.

[8]. Dogan SF, Sahin S, Sumnu G. 2005. Effects of soy and rice flour addition on batter rheology and quality of deep-fat fried chicken nuggets. Journal of Food Engineering. 71: 127-132.

[9]. Erkan N, Ozden O, Selcuk A. 2010. Effect of frying, grilling, and steaming on amino acid composition of marine fishes. Journal of Medicinal Food 13(6):1524-1531.

[10]. Garayo J, Moreira R. 2002. Vacuum frying of potato chips. Journal of Food Engineering. 55:181-191.

[11]. Gerrard JA. 2002. Protein-protein crosslinking in food: methods, consequences, applications. Trends Food Science and Technology.13 (12): 391-397. 
[12]. Gokoglu N, Yerlikaya P, Cengiz E. 2004. Effects of cooking methods on the proximate composition and mineral contents of rainbow trout (Oncorhynchus mykiss). Food Chemistry. 84:19-22.

[13]. Iguttia AM, Pereira ACI, Fabiano L, Silva RAF, Ribeiro EP. 2011. Substitution of ingredients by green coconut (Cocos nuciferaL) pulp in ice cream formulation. Procedia Food Science 1:1610-1617.

[14]. Jirapong CA, Uthairatanakij, Noichinda S, Kanlayanarat S, Wongs AC. 2010. Comparison of volatile compounds between fresh and heatprocessed aromatic coconut abstrak]. Di dalam: Kanlayanarat S, Boonyaritthongchai P, Acedo AL, editor. Asia Pacific Symposium on Postharvest Research, Education and Extension. Bangkok, 28 Februari 2012. Bangkok: ISHS Acta Horticulturae. Hlm 943.

[15]. Karmiati. 2011. Pengaruh berbagai jenis tepung terhadap makanan tradisional tumpi-tumpi ikan cakalang (Katsuwonus pelamis L) skripsi]. Makassar: Fakultas Pertanian Universitas Hasanuddin.

[16]. Ketaren S. 1986. Pengantar Teknologi Minyak dan Lemak Pangan. Jakarta: Universitas Indonesia Press.

[17]. Kumar AJ, Singh RRB, Patel AA, Patil GR. 2006. Kinetics of colour and texture changes in Gulabjamun balls during deep-fat frying. Lebensmittel Wissenschaft and Technologie. 39:827-833.

[18]. Lin FM, Wilkens WF. 2006. Volatile flavor components of coconut meat. Journal of Food Science 35(5): 538-539.

[19]. Marimin, Maghfiroh N. 2011. Aplikasi Teknik Pengambilan Keputusan dalam Manajemen Rantai Pasok. Bogor: IPB Press.

[20]. Martin C, Prada EM, Meinders MBJ, Vereijken PFG, Vliet T. 2008. Effect of structure in the sensory characterization of the crispness of toasted rusk roll. Food Research International. 41(5): 480-486.

[21]. Moreno MC, Brown CA, Bouchon P. 2010. Effect of food surface roughness on oil uptake of deepfat fried food. Journal of Food Engineering. 101:179-186.

[22]. Moyano PC, Rioseco VK, Gonzalez PA. 2002. Kinetics of crust color changes during deep-fat frying of impregnated French fries. Journal of Food Engineering. 54: 249-255.

[23]. Muchtadi TR, Ayustaningwarno F. 2010. Teknologi Proses Pengolahan Pangan. Bogor: IPB Press.

[24]. Ndife J, Abdulraheem LO, Zakari UM. 2011. Evaluation of the nutritional and sensory quality of functional breads produced from whole wheat and soya bean flour blends. African Journal of Food Science 5(8): 466-472.

[25]. Santoso J, Gunji S, Stark YY, Suzuki T. 2006. Mineral contents of Indonesian seaweeds and mineral solubility affected by basic cooking. Food Science Technology Research. 12(1): 59-66.

[26]. (SNI) Standar Nasional Indonesia. 1992. Cara uji karbohidrat makanan dan minuman. SNI 012891-1992. Jakarta: BSN.

[27]. (SNI) Standar Nasional Indonesia. 2006. Cara uji kimia- Bagian 2: Penentuan kadar air pada produk perikanan. SNI-01-2354.2-2006. Jakarta: BSN ICS 67.120.30.

[28]. (SNI) Standar Nasional Indonesia. 2006. Cara uji kimia - Bagian 3: Penentuan kadar lemak total pada produk perikanan. SNI 01-2354.3-2006. Jakarta: BSN ICS 67.120.30.

[29]. (SNI) Standar Nasional Indonesia. 2006. Cara uji kimia - Bagian 4: Penentuan kadar protein dengan metode total nitrogen pada produk perikanan. SNI 01-2354.4-2006. Jakarta: BSN ICS 67.120.30.

[30]. (SNI) Standar Nasional Indonesia. 2006. Petunjuk pengujian organoleptik dan atau sensori. SNI 01.2346:2006. Jakarta: BSN ICS 67.240. 
[31]. (SNI) Standar Nasional Indonesia. 2010. Cara uji kimia - Bagian 1: Penentuan kadar abu dan abu tak larut dalam asam pada produk perikanan. SNI 2354.1:2010. Jakarta: BSN ICS 67.050.

[32]. Solangi AH, Iqbal MZ. 2011. Chemical composition of meat (kernel) and nut water of major coconut (Cocos nucifera L.) cultivars at coastal area of Pakistan. Pakistan Journal Botanical. 43(1): 357-363.

[33]. Steel RGD, Torrie JH. 1995. Prinsip dan Prosedur Statistika: suatu pendekatan biometrik. Penerjemah, editor. B. Sumantri. Jakarta: Gramedia Pustaka Utama.

[34]. Suhardi, Bonimin. 2011. Pengaruh penambahan tapioka terhadap mutu 'brondong' jagung dengan menggunakan ekstruder. Di dalam: Mahfud C et al., editor. Pengelolaan Sumberdaya Pertanian Mendukung Kemandirian Pangan Rumah Tangga Petani. Prosiding seminar Nasional, Malang, 3 Desember 2011. Malang: Balai Pengkajian Teknologi Pertanian Jawa Timur, bekerjasama dengan Fakultas Pertanian Universitas Brawijaya Malang, Kontak Tani Nelayan Andalan (KTNA) Pusat, dan Dinas Pertanian Provinsi Jawa Timur. hlm 409-414.

[35].Suyanti. 2011. Diversifikasi produk olahan berbasis sukun. Sinartani Agroinovasi Badan Litbang Pertanian. 43(3431):11-12.

[36]. Swastawati F, Agustini TW, Darmanto YS, Dewi EN. 2007. Liquid smoke performance of lamtoro wood and corn cob. Journal of Coastal Development. 10(3): 189-196.

[37]. Syahrul, Syarief R, Hermanianto J, Nurtama B. 2017. Optimasi proses penggorengan tumpitumpi dari ikan bandeng menggunakan response surface methodology. Jurnal Pengolahan Hasil Perikanan Indonesia. 20(3): 432-445.

[38]. Turkkan UA, Cakli S, Kilinc B. 2008. Effects of cooking methods on the proximate composition and fatty acid composition of seabass (Dicentrarchus labrax, Linnaeus, 1758). Food and Bioproducts Processing 86:163-166.
[39]. Waisundara VY, Perera CO, Barlow PJ. 2007. Effect of different pre-treatments of fresh coconut kernels on some of the quality attributes of the coconut milk extracted. Food Chemistry. 101: 771-777.

[40]. Winarno FG, Wirakusumah ES, Fardiaz D, Kusdinar T, Rimbawan 1999. Kumpulan makanan traditional I. Bogor: PKMT-PT Depdikbud.

[41].Zamora R, Hidalgo ZJ. 2005. Coordinate contribution of lipid oxidation and Maillard reaction to the nonenzymatic food browning. Critical Reviews in Food Science and Nutrition: ProQuest Agriculture Journal. 45(1):49

Cite this article as : Tien Kumalasari, Agussalim Matti, "Evaluation and Reformulation of Ingredients the Indigenous Tumpi Product", International Journal of Scientific Research in Science and Technology (IJSRST), Online ISSN : 2395-602X, Print ISSN : 2395-6011, Volume 6 Issue 1, pp. 358-372, January-February 2019.

Available at doi : https://doi.org/10.32628/IJSRST196134 Journal URL : http://ijsrst.com/IJSRST196134 